\title{
THE CRINOIDS OF THE MUSEUM FUER NATURKUNDE, BERLIN.
}

\author{
By Austin Hobart Clark, \\ Assistant Curator, Division of Marine Invertebrates, U. S. National Museum.
}

\section{PREFACE.}

Shortly after I began the study of the recent crinoids Drs. W. Weltner and R. Hartmeyer of the Museum für Naturkunde offered me for study the collection which had been brought together by the German steamer Gazelle on her memorable voyage in 1874-1876. When the work on this material was completed these gentlemen most generously offered me the entire collection of their museum, which was sent to Washington in order that I might compare the specimens directly with those in the collection of the United States National Museum. The debt of gratitude which I owe to Drs. Weltner and Hartmeyer for their kindness can only be appreciated when it is remembered that the collection includes the types of many of the species described by Prof. Johannes Müller in 1841 and 1849, and by Dr. Clemens Hartlaub in 1890.

During the summer of $1910 \mathrm{I}$ visited Berlin and examined the few specimens which had not been sent to me, and also some others which had been recently received.

The Museum für Naturkunde has generously permitted the United States National Museum to retain a number of the specimens belonging to their collection, and to have photographs made of all the specimens of particular interest.

The species represented by the specimens retained, and the localities, are the following:

Comissia hartmeyeri, new species, Eig Tor, Gulf of Suez.

Comatulella brachiolata (Lamarck), Koombana Bay, Western Australia.

Comatula purpurea (J. Müller), Useless Inlet, Shark Bay, Western Australia. Australia.

Comatula purpurea (J. Müller), Freycinet Reach, Shark Bay, Western

Comanthus wahlbergir (J. Müller), Port Natal.

Amphimetra africana A. H. Clark, Bagamoyo, German East Africa.

Craspedometra madagascarensis A. H. Clark, Madagascar.

Heterometra savignir (J. Müller), Red Sea. 
Selenemetra finschil (Hartlaub), New Britain.

Dichrometra palmata (J. Müller), Red Sea.

Dichrometra protectus (Lütken), New Guinea.

Decametra modica A. H. Clark, Bagamoyo.

Oligometra occidentalis A. H. Clark, Bagamoyo.

Tropiometra carinata (Lamarck), Fouquet Reef, Mauritius.

Tropiometra picta (Gay), Rio de Janeiro.

Ptilometra macronema (J. Müller), Koombana Bay.

Antedon adriatica A. H. Clark, Trieste.

Compsometra incommoda (Bell), Koombana Bay.

Iridometra mauritiana A. H. Clark, Mauritius.

Leptometra phalangium (J. Müller), Nice.

Leptometra phalangium (J. Müller), Sicily.

Hathrometra prolixa (Sladen), Norwegian Sea.

Hathrometra prolixa (Sladen), Spitzbergen.

(The specimens given in small capitals are cotypes of the species.)

HISTORICAL ACCOUNT OF THE COLLECTION.

The first notices of specimens in the Museum für Naturkunde were published by Prof. Johannes Müller, who made a number of them the types, and others the types in part, of new species described in 1841,1843 , and 1849 .

In 1869 Prof. E. von Martens recorded some specimens which had been brought back by Count von der Decken from his trip to East Africa, while in 1877, and again in 1887, Prof. Ludwig von Graff mentioned, as hosts for Myzostoma described by him, a few more.

In the preparation of the Challenger report upon the comatulids (published in 1888) Dr. P. H. Carpenter visited the museum and studied the collections, paying particular attention to the types of Müller's species; but he never published any detailed account of them, merely including references to a few forms in his monograph.

In the following year Prof. Th. Studer published some records of comatulids which had been collected by the Gazelle during her trip to the East Indies and to Western Australia. These records were mostly indefinite, giving only the genus to which the animals belonged. Later the material was sent to Doctor Carpenter for more accurate determination, but he was unable to complete a report upon it before he died.

In 1890 Dr. Clemens Hartlaub published preliminary diagnoses of several new species based upon the material in this museum, in the following year describing them in greater detail and figuring them, and also recording many others not previously noticed.

The specimens recorded by Prof. Ludwig Döderlein in the Fauna Arctica, which were collected by Römer and Schaudinn at Spitzbergen, are in the collection of this museum.

In 1909 the Gazelle crinoids were sent to the present author; two new species were described from among them, and later a general 
account of the collection was published. Two years later the same author published a monograph of the recent crinoids of Africa based largely upon specimens in this collection, and an account of the crinoids of the Hamburg west Australian expedition, also based upon specimens now in part in this museum. In addition a few records gathered from the data on the labels of the specimens have been included in his monographs of the recent crinoids of Australia, and of the crinoids of the Indian Ocean.

\section{TYPES IN THE COLLECTION.}

The collection of the Museum für Naturkunde contains the following specimens, which are either types, or were considered in the drawing up of the original diagnoses:

Alecto rosea J. Müller, 1841 (Monatsb. k. preuss. Akad. Wiss., 1841, p. 183; Archiv Naturg., 1841, vol. 1, p. 143; Die Gattung Comatula, p. 250).

=COMATULELLA BRACHIOLATA (Lamarck). ${ }^{1}$

Alecto echinoptera J. Müller, 1841 (Monatsb. k. preuss. Akad. Wiss., 1841, p. 183; Archiv Naturg., 1841, vol. 1, p. 143; Die Gattung Comatula, p. 250).

=COMACTINIA ECHinOptera (J. Müller).

Alecto phalangium J. MüLLER, 1841 (Monatsb. k. preuss. Akad. Wiss., 1841, p. 182; Archiv Naturg., 1841, vol. 1, p. 142; Die Gattung Comatula, p. 253).

=LePtometra phaLANGiUm (J. Müller).

Alecto eschrichtii J. Müller, 1841 (Monatsb. k. preuss. Akad. Wiss., 1841, p. 183; Archiv Naturg., 1841, vol. 1, p. 142; Die Gattung Comatula, p. 254).

$=$ HeLiometra GLACIALIS (Leach).

Alecto savignï J. Müller, 1841 (Monatsb. k. preuss. Akad. Wiss., 1841, p. 185; Archiv Naturg., 1841, vol. 1, p. 144; Die Gattung Comatula, p. 257).

$$
\begin{aligned}
& =\text { Heterometra savignil (J. Müller)+ } \\
& \text { Craspedometra ater A. H. Clark. }
\end{aligned}
$$

Alecto palmata J. Müller, 1841 (Monatsb. k. preuss. Akad. Wiss., 1841, p. 185; Archiv Naturg., 1841, vol. 1, p. 144; Die Gattung Comatula, p. 261).

$$
=\text { Dichrometra palmata (J. Müller). }{ }^{2}
$$

Alecto wahlbergii J. Müller, 1843 (Archiv Naturg., 1843, vol. 1, p. 131; Die Gattung Comatula, p. 256).................. = Comanthus wahlbergir (J. Müller).$^{3}$

Alecto purpurea J. Müller, 1843 (Archiv Naturg., 1843, vol. 1, p. 132; Die Gattung Comatula, p. 248)...................... = Comatula purpurea (J. Müller).

Comatula cumingii J. Müller, 1849 (Die Gattung Comatula, p. 255).

=Comatula Pectinata (Linnæus).

Antedon martensi Hartlaub, 1890 (Nachr. Ges. Göttingen, Mai 1890, p. 170; Die Comatulidenfauna des Indischen Archipels, p. 21, pl. 1, figs. 3 and 6).

= HIMEROMETRA Crassipinna (Hartlaub).

Antedon finschii Hartlaub, 1890 (Nachr. Ges. Göttingen, Mai 1890, p. 176; Die Comatulidenfauna des Indischen Archipels, p. 47, pl. 3, fig. 32).

=Selenemetra finschit (Hartlaub).

Antedon tenuipinna Hartlaub, 1890 (Nachr. Ges. Göttingen, Mai 1890, p. 178; Die Comatulidenfauna des Indischen Archipels, p. 54, pl. 3, figs. 28, 30, and 34).

$=$ StePhaNOMETRA TENUIPINNA (Hartlaub).

1 The other specimens included in the original diagnosis are in the Vienna Museum.

2 Only the specimens collected by Hempricht and Ehrenberg in the Red Sea belong to this species; those collected by Eschricht in India, and those from Zamboanga in the Paris Museum which he mentions, are examples of $D$. protectus.

${ }^{3}$ The other specimens included in the original diagnosis are in the Stockholm Museum. 
Antedon conifera Hartlaub, 1890 (Nachr. Ges. Göttingen, Mai 1890, p. 173; Die Comatulidenfauna des Indischen Archipels, p. 76, pl. 4, fig. 46; pl. 5, figs. 51 and 56).

= COSMIOMETRA CONIFERA (Hartlaub).

Antedon japonica Hartlaub, 1890 (Nachr. Ges. Göttingen, Mai 1890, p. 172; Die Comatulidenfauna des Indischen Archipels, p. 84, pl. 5, fig. 49).

=OLigOMETRA JAPONICA (Hartlaub).

Ptilometra dorcadis A. H. Clark, 1909 (Proc. Biol. Soc. Washington, vol. 22, p. 39; Bull. mus. hist. nat., 1911, No. 4, pp. 244, 255, fig. 1 B).

=Ptilometra macronema (J. Müller).

Oligometra studeri A. H. Clark, 1909 (Proc. Biol. Soc. Washington, vol. 22, p. 41; see also p. 88) ............................

Amphimetra africana A. H. Clark, 1911 (Proc. U. S. Nat. Mus., vol. 40, p. 20).

= AMPHIMETRA AFricana A. H. Clark.

Craspedometra ater A. H. Clark, 1911 (Proc. U. S. Nat. Mus., vol. 40, p. 21).

=Craspedometra ATER A. H. Clark.

Craspedometra madagascarensis A. H. Clark, 1911 (Proc. U. S. Nat. Mus., vol. 40, p. 23). = Craspedometra MADAGASCARENSIS A. H. Clark.

Decametra möbiusi A. H. CLARK, 1911 (Proc. U. S. Nat. Mus., vol. 40, p. 31).

= DeCAMETRA möBiUSi A. H. Clark.

Decametra modica A. H. Clark, 1911 (Proc. U. S. Nat. Mus., vol. 40, p. 32).

=DECAMETra Modica A. H. Clark.

Oligometra serripinna var. occidentalis A. H. Clark, 1911 (Proc. U. S. Nat. Mus., vol. 40 , p. 33) ........................ Oligometra s. occidentalis A. H. Clark.

Tropiometra encrinus A. H. Clark, 1911 (Proc. U. S. Nat. Mus., vol. 40, p. 36).

=Tropiometra encrinus A. H. Clark+

Tropiometra AUDOUINI, new species+

Tropiometra INDICA, new species.

Iridometra mauritiana A. H. ClakK, 1911 (Proc. U. S. Nat. Mus., vol. 40, p. 40).

=Iridiometra mauritiana A. H. Clark.

\section{RECORDED SPECIMENS OTHER THAN TYPES.}

The following references to specimens, other than types, in the collection of the Museum für Naturkunde appear in the literature:

Pentacrinus caput-Medusæ Lamarck; J. Müller, 1843 (Abh. k. preuss. Akad. Wiss., 1841, p. 185) ............................ = IsOCRINUS ASTERIA (Linnæus).

Comatula (Alecto) carinata Lamarck; J. Müller, 1849 (Abh. k. preuss. Akad. Wiss., 1847 , p. 252 ; Mauritius).................... Comatula (Alecto) mediterranea Lamarck; J. Müller, 1849 (Abh. k. preuss. Akad. Wiss., 1847, p. 252).

(a) Specimens from Trieste.............. AnTEdon AdRIATICA A. H. Clark.

(b) Specimens from Marseilles and Nice.=Antedon Mediterranea (Lamarck). Comatula (Alecto) sarsii Düben and Koren; J. Müller, 1849 (Abh. k. preuss. Akad.

Wiss., 1847, p. 254)................ = HAthrometra SARSII (Düben and Koren). Eudiocrinus japonicus P. H. Carpenter; P. H. Carpenter, 1888 (Challenger Report, p. 85 ; Japan)................ Pe Pentametrocrinus tuberculatus (A. H. Clark). Antedon carinata (Lamarck); P. H. CaRpenter, 1888 (Challenger Report, p. 202) =TROPIOMETRA CARINATA (Lamarck) +

TROPIOMETRA AUDOUINI, new species +

TROPIOMETRA INDICA, new species.

Actinometra purpurea (J. Müller); P. H. CARPenter, 1888 (Challenger Report, p. 278; tentative synonym of Act. pectinata) . . . . . . . Comatula purpurea (J. Müller). 
Actinometra rosea (J. Müller); P. H. Carpenter, 1888 (Challenger Report, p. 278; synonym of Act. brachiolata).......... = Comatulella BRACHIolAta (Lamarck). Actinometra coppingeri Bell; P. H. Carpenter, 1888 (Challenger Report, p. 321).

= CAPILLASTER MULTIRAdIATA (Linnæus).

Actinometra parvicirra (J. Müller); P. H. CARPENTER, 1888 (Challenger Report, p. 342;

Batjan) . . . . . . . M . Antedon palmata.(J. Müller); HaRtLAub, 1891 (Die Comatulidenfauna des Indischen Archipels, p. 51).

(a) Five from the Red Sea; Hempricht and Ehrenberg.

=Dichrometra palmata (J. Müller).

(b) Two from the Red Sea; "Antedon sp." P. H. Carpenter, MS.

(c) Red Sea; Jar No. $2019 \ldots \ldots \ldots \ldots \ldots$. . . . Dichrometra Palmata (J. Müller).

(d) Singapore; Jagor.................. Dichrometra PRotectus (Lütken.) ${ }^{2}$ Antedon tuberculata P. H. Carpenter; Hartlaub, 1891 (Die Comatulidenfauna des Indischen Archipels, p. 57; no data given).

=Stephanometra tuberculata (P. H. Carpenter) Antedon imparipinna P. H. Carpenter; Hartlaub, 1891 (Die Comatulidenfauna des Indischen Archipels, p. 65; Tonga Islands; Batjan; New Guinea).

=DICHROMETRA PROTECTUS (Lütken). ${ }^{3}$

Antedon flagellata (J. Müller); HaRtıAub, 1891 (Die Comatulidenfauna des Indischen

Archipels, p. 75 ; Singapore) ........... =Dichrometra flagellata (J. Müller.) ${ }^{4}$ Capillaster multiradiata (Linnæus); A. H. ClaRK, 1909 (Zool. Anzeiger, vol. 34, p. 364). = CAPILlaster mUltiradiata (Linnæus).

Comaster typica (Lovén); A. H. ClaRk, 1909 (Zool. Anzeiger, vol. 34, p. 365). = COMASTER TYPICA (Lovén).

Comanthus rotalaria (Lamarck); A. H. Clark, 1909 (Zool. Anzeiger, vol. 34, p. 365). = CoMANTHUS PARVicirRa (J. Müller).

Comanthus briareus (Bell); A. H. Clark, 1909 (Zool. Anzeiger, vol. 34, p. 365). = COMANTHERIA BRIAREUS (Bell).

Zygometra microdiscus (Bell); A. H. Clark, 1909 (Zool. Anzeiger, vol. 34, p. 367). =ZYGOMETRA MICRODISCUS (Bell).

Zygometra elegans (Bell); A. H. Clark, 1909 (Zool. Anzeiger, vol. 34, p. 367).

=ZYGOMETRA ELEGANS (Bell).

Dichrometra protectus (Lütken); A. H. ClARK, 1909 (Zool. Anzeiger, vol. 34, p. 367). =Dichrometra PROTECTUS (Lütken).

Dichrometra palmata (Müller); A. H. ClaRK, 1909 (Zool. Anzeiger, vol. 34, p. 367). =Dichrometra PROTECTUS (Lütken).

Comanthus (Validia) parvicirra (J. Müller); A. H. ClaRK, 1911 (Proc. U. S. Nat. Mus., vol. 40 , p. 18).

(a) Seychelles; Berlin Museum.............. = Comissia ignota A. H. Clark.

(b) Red Sea; Dr. Hartmeyer ............ Comissia HARTMEYeRI, new species. Cenometra emendatrix (Bell); A. H. Clark, 1911 (Proc. U. S. Nat. Mus., vol. 40, p. 28). =CENOMETRA EMENDATRIX (Bell).

\footnotetext{
${ }^{1}$ Carpenter also, in summing up all that is known about the recent comatulids, mentions all the species which were described by Professor Müller from specimens in the Museum für Naturkunde.

2 For information in regard to the specimen from Djeddah, see Notes from the Leyden Museum, vol. 33, p. 187.

3 Doctor Hartlaub calls attention to the fact that Müller in describing Alecto palmata gives the number of arms as 35-40, whereas true palmata has but 30; Müller's diagnosis of palmata was partly based upon specimens of Dichrometra protectus, a 40-armed species, and he seems to have taken the arm number from these. Müller's specimens of palmata from India and from Zamboanga (Die Gattung Comatula, p. 261) are both representatives of protectus.

1 For the synonymy of this species see Notes from the Leyden Museum, vol. 33, p. 184.
}

$$
48702^{\circ} \text {-Proc.N.M.vol.43-12-25 }
$$


ANNOTATED LIST OF THE SPECIES.

Family COMASTERID正.

Subfamily CAPIITASTERIN A..

COMATELlA STElligeRA (P. H. Carpenter).

[For the synonymy, see Vid. Medd. naturh. For. Kфbenhavn, 1909, p. 136; and The Crinoids of the Indian Ocean.]

1. New Guinea; Cat. No. 5347.--One small specimen with 30 arms; the cirri are XIV, 19-21.

\section{CAPILLASTER MULTIRADIATA (Linnæus).}

[For the synonymy, see Vid. Medd. naturh. For. Kфbenhavn, 1909, p. 134; Proc. U. S. Nat. Mus., vol. 40, p. 16; and The Crinoids of the Indian Ocean.]

1. Dirk Hartog Island, Western Australia; Gazelle.-One specimen (see Zool. Anzeiger, vol. 34, No. 11/12, p. 364).

2. Amboina; Professor von Martens; Cat. No. 1329.-One specimen with 20 arms $115 \mathrm{~mm}$. long.

3. St. Mathias Island; Herr H. Schöde.-One small specimen.

4. Singapore; Professor von Martens; Cat. No. 2455.-One 13armed specimen.

5. British North Borneo; Herr Pagel; Cat. No. 4744.--Two specimens; one of these has about 25 arms $110 \mathrm{~mm}$. long, the IIIBr series all $3(2+3)$, always internal; the other has 19 arms $85 \mathrm{~mm}$. long, no IIIBr series being present.

6. ? China; Cat. No. 5285.-One small specimen with 31 arms 80 $\mathrm{mm}$. long.

7. No locality.-One specimen.

COMISSIA IGNOTA A. H. Clark.

Comissia ignota A. H. Clark, Proc: U. S. Nat. Mus., vol. 40, 1911, p. 17.

1. Seychelles; Professor Brauer; Cat. No. 4745.-One specimen.

COMISSIA HARTMEYERI, new species.

Description.-Centrodorsal thin discoidal, the dorsal pole flat, about $1 \mathrm{~mm}$. in diameter.

Cirri VIII-XIV (usually about X), 10-13 (usually 12 or 13 ), 4.5 to $6 \mathrm{~mm}$. (usually about $5 \mathrm{~mm}$.) long. The first segment is short, - the second about as long as broad, the third from two to three times as long as its median diameter; the fourth segment is the longest, three and one-half to four times as long as the median diameter; the fifth is not quite so long; the following segments rapidly decrease in length so that the ninth and following are about as long as broad; the fifth is a transition segment; the longer proximal segments are oval in cross section and are strongly "dice-box shaped," but the outer short segments have straight sides and are strongly compressed 
laterally, therefore appearing broad in lateral view. The transition and following segments have the distal dorsal edge everted, forming a minute sharp tubercle in lateral view, at first subterminal but becoming median on the antepenultimate; the opposing spine is represented by a minute median tubercle only slightly larger than the tubercle on the preceding segment; the terminal claw is slightly longer than the penultimate segment, rather stout, and strongly curved, more so basally than distally.

The radials are even with the edge of the centrodorsal in the median line, but extend up interradially and entirely separate the bases of the $I_{B} r_{1}$; the $I B r$ series are widely separated, their sides making nearly a right angle with the sides of the adjacent $\mathrm{IBr}$ series. The union of the elements of the $\mathrm{IBr}$ series is very close, appearing almost like a syzygy in external view.

The 10 slender arms are from 30 to $39 \mathrm{~mm}$. long; the brachials, which are proportionately long, have strongly produced and overlapping spinous distal ends.

The mouth is marginal and the anal tube subcentral; the anal area is completely covered with small thin calcareous plates.

Locality.-Eig Tor, Gulf of Suez, Red Sea. Eight specimens, collected by Dr. Robert Hartmeyer.

Remarks.-The type material consists of eight specimens. That which was selected as the type-specimen has the arms $30 \mathrm{~mm}$. long; the cirri are IX, 11-13, 5 to $6 \mathrm{~mm}$. long; syzygies occur between the third and fourth brachials, again between the tenth and eleventh or eleventh and twelfth (usually the latter) and fourteenth and fifteenth to seventeenth and eighteenth, and distally at intervals of three (more rarely two) oblique muscular articulations. Another specimen has the arms $33 \mathrm{~mm}$. long, and the cirri VIII, $10,4.5 \mathrm{~mm}$. long. A third has the arms $39 \mathrm{~mm}$. long, and the cirri XIV, 11-12 (usually the latter) $5 \mathrm{~mm}$. long. A fourth has the cirri IX, 12-13. The remaining four specimens are similar to these.

The type-specimen is in the Berlin Museum.

\section{Subfamily COMACTINIIN AE.}

COMATULELLA BRACHIOLATA (Lamarck).

[For the synonymy, see The Recent Crinoids of Australia.]

1. Australia; Herr Preiss; Cat. No. 1048 (Types of Alecto rosea J. Müller, 1841).-Two fragmentary specimens.

The centrodorsal is very large and massive, thick-discoidal, with a very slightly convex polar area $7 \mathrm{~mm}$. in diameter; the cirrus sockets are arranged in a single crowded, slightly irregular marginal row.

The cirri are XX-XXII, 32-34, $15 \mathrm{~mm}$. long, rather slender, decreasing slightly in diameter from the base to about the eighth segment, then remaining the same to near the end, the terminal 
portion again tapering slightly; the first segment is very short, the following very gradually increasing in length to the eighth which, with the following, is about twice as broad as long; the penultimate segment is about as long as broad; after the seventh or eighth segment the dorsal profile of the segments becomes very strongly, but evenly, convex, so that in a lateral view the dorsal edge of the cirri appears to be strongly scalloped; the opposing spine is small and blunt, inconspicuous; the terminal claw is small and blunt.

The radials are concealed by the centrodorsal; the $\mathrm{IBr}_{1}$ are very short, oblong, almost or quite united laterally, united to the $\mathrm{IBr}_{2}$ by cryptosynarthry, the two ossicles together forming a pentagonal element about twice as broad as long; the $\mathrm{IBr}_{2}$ are free laterally.

The 10 arms are apparently 60 or $65 \mathrm{~mm}$. long; they are excessively stout in the basal half, the brachials measuring between 3 and $4 \mathrm{~mm}$. in transverse diameter; the dorsal surface of the arms is peculiarly flattened; the first brachial is exceedingly short, forming what appears superficially to be a syzygial pair with the second, this pair being wedge-shaped, about twice as broad as the median length, interiorly united; the third and fourth brachials (syzygial pair) are wedge-shaped, about twice as broad as their inner (greater) length; the following brachials are slightly wedge-shaped, about three times as broad as the median length, gradually becoming triangular, two and one-half or three times as broad as the longer side; the whole arm presents an exceptionally rugged appearance.

$\mathrm{P}_{1}$ is $13 \mathrm{~mm}$. long, and is composed of 30 segments, of which the first 3 or 4 are broader than long, and the remainder are about as long as broad; none of the segments are carinate; the terminal comb has 11 teeth, which are bluntly triangular, rather narrow basally, about as high as the lateral diameter of the segment that bears them; $P_{2}$ is similar but not so long, as stout basally as $\mathrm{P}_{1}$ but, owing to the lesser length, tapering slightly more rapidly; $\mathrm{P}_{3}$ is similar, $8.5 \mathrm{~mm}$. long, with 21 segments, almost all of which are broader than long, as stout basally as $\mathrm{P}_{2}$ but becoming more slender distally; this pinnule bears no comb; the following pinnules are apparently similar to $\mathrm{P}_{3}$, gradually becoming more slender distally with longer segments, the change taking place first in the distal portion of the pinnules and working toward the base, and slightly decreasing in length. The segments in the proximal part of the pinnules following the third are more or less produced in a thickened convexity dorsally, this dying away in the outer half of the pinnule; this slowly disappears in the distal half of the arm.

The color in spirits is yellow.

2. Southwestern Australia.-Four specimens. (See Die Fauna Südwest-Australiens, vol. 3, Lief. 13, p. 447.) 
COMATULA PURPUREA (J. Müller).

[For the synonymy, see The Recent Crinoids of Australia.]

1. Australia; Herr Preiss; Cat. No. 1049 (Type of Alecto purpurea J. Müller, 1841).--One specimen. (See Proc. Biol. Soc. Washington, vol. 23, p. 95.)

2. Southwestern Australia.-Fourteen specimens. (See Die Fauna Südwest-Australiens, vol. 3, Lief. 13, p. 451.)

COMATULA PECTINATA (Linnæus).

[For the synonymy, see Vid. Medd. naturh. For. K $\varnothing$ benhavn, 1909, p. 148; and The Crinoids of the Indian Ocean.]

1. Banka Strait; Prof. E. von Martens; Cat. No. 1842.--One small specimen with arms about $70 \mathrm{~mm}$. long.

2. British North Borneo; Herr Pagel; Cat. No. 4744.- One specimen of the slender armed type, with arms $120 \mathrm{~mm}$. long.

3. Malacca; Mr. Hugh Cuming; Cat. No. 1051 (type of Comatula cumingii J. Müller, 1849). - One young specimen with arms $35 \mathrm{~mm}$. long; the cirri are VII, all broken off at the base.

COMACTINIA MERIDIONALIS (A. and E. C. Agassiz).

Alecto meridionalis A. and E. C. AgAssiz, Seaside Studies, 1865, p. 121.

1. French Reef; United States Coast Survey; Cat. No. 2962.-One specimen.

COMACTINIA ECHINOPTERA (J. Müller).

1. Nolocality; Captain Wendt.-One medium sized specimen, resembling others in the collection of the United States National Museum from Cuba and from other parts of the West Indies.

Hartlaub ${ }^{1}$ states that, according to Carpenter, Comactinia echinoptera is identical with the "10-armed variety" of Neocomatella alata.

The genus Comactinia is very closely allied to the genera Comatula and Cominia, which it represents in the West Indian region. In his discussion of the genus Comatula (the "Solaris" and "Paucicirra Groups" of Actinometra) Carpenter placed the most weight upon the presence of syzygies between the ossicles of the $\mathrm{IBr}$ series, this character separating it sharply from the West Indian Comactinia (the "Echinoptera Group"). This supposed syzygy, however, is not a syzygy at all, but in reality a peculiar modification of the ordinary articulation occurring in that position, not in any way comparable to the true syzygy. ${ }^{2}$ Moreover, it is not always developed, even in a given species; for instance, some individuals of Comatula pectinata have it and many do not. It affords, therefore, no basis whatever for the differentiation of the genera Comatula and Comactinia, or

1 Die Comatulidenfauna des Indischen Archipels, p. 105.

2 Proc. Biol. Soc. Washington, vol. 22, p. 173. 
for the differentiation of the "Solaris" and "Echinoptera Groups." Comatula and Comactinia, together with a few other similar genera, are sharply distinguished from sll the other genera of the family Comasteride by certain peculiarities of the cirri and of the genital pinnules, and have therefore been grouped together into the subfamily Comactiniinæ. ${ }^{1}$

The genus Neocomatella is very elosely related to the genus Comatella, which it replaces in the West Indian region. Both have a very curious type of arm division, which is closely akin to that found in the genera Nemaster and Capillaster, and quite different from that of any other type. All of these show, in the structure of their cirriand pinnules, a close relationship to such of the 10-armed comasterids as possess dorsal spines on the outer cirrus segments, and for that reason have been united with them in the subfamily Capillasterinæ. ${ }^{1}$ No species at all closely related to Neocomatella alata is known which possesses only 10 arms, nor is that species ever found in a 10-armed condition. There are, however, many 10-armed species, especially in the West Indies, belonging to the allied genera, but all of them are sharply differentiated from the species of Comactinia by the presence of dorsal spines on the outer cirrus segments, as well as by the much longer and narrower segments of the genital pinnules.

It is difficult to see how Carpenter could have supposed that Comactinia echinoptera, belonging to the subfamily Comactiniinæ, is merely a 10-armed form of Neocomatella alata, belonging to the subfamily Capillasterinæ.

\section{Subfamily COMIASTFRINA. \\ COMASTBR TYPICA (Lovén).}

[For the synonymy, see Vid. Medd. Naturh. For. Kobenhavn, 1909, p. 139.]

1. North of Port Walcott, Western Australia; 50 fathoms; Gazelle.One specimen. (See Zool. Anzeiger, vol. 34, No. 11/12, p. 365.)

2. Southwestern Australia.-Five specimens. (See Die Fauna Sūdwest-Australiens, vol. 3, Lief. 13, p. 453.)

COMANTHBRIA BRIARBUS (Bell).

[For the synonymy, see The Crinoids of the Indisn Ocesn.]

1. North of Port Walcott, Western Australia; 50 fathoms; Gazelle.One specimen. (See Zool. Anzeiger, vol. 34, No. 11/12, p. 365.)

2. Southwestern Australia.-Two specimens. (See Die Fauna Sūdwest-Australiens, vol. 3, Lief. 13, p. 454.)

COMANTHINA BBLLI (P. H. Carpenter).

[For the synonymy, see The Recent Crinoids of Australia]]

1. Mermaid, northwestern Australia; Gazelle; Cat. No. 2157.-Arm fragments; the extravagant dorsal processes on the third, fourth, and 
fifth, and to a lesser degree on the sixth, pinnule segments prove conclusively that these fragments must belong to this species. They agree very closely with corresponding parts of the arms in a fine specimen at hand from Torres Strait.

2. Southwestern Australia.-Two specimens. (See Die Fauna Südwest-Australiens, vol. 3, Lief. 13, p. 455.)

COMANTHINA SCHLEGELII (P. H. Carpenter).

[For the synonymy, see Notes from the Leyden Museum, vol. 33, p. 179.]

1. Amboina; Dr. J. Brock; Cat. No. 5286.-One fine specimen; two fully developed and several rudimentary cirri remain. This specimen has already been recorded by Hartlaub, under the name of Actinometra regalis. (See Die Comatulidenfauna des Indischen Archipels, p. 99.)

\section{COMANTHUS BENNETTI (J. Müller).}

[For the synonymy, see The Crinoids of the Indian Ocean.]

1. South Seas; Dr. O. Finsch; Cat. No. 5350.-One fine specimen with about 70 arms about $160 \mathrm{~mm}$. long.

2. St. Mathias Island; Herr H. Schöde.-Five specimens, all rather small, with about 60 arms. The distal cirrus segments are laterally flattened and about twice as broad as long, but perfectly smooth dorsally. One of the specimens is unusual in having several of the division series of 2 instead of the usual $4(3+4)$.

COMANTHUS SAMOANA A. H. Clark.

[For the synonymy, see The Crinoids of the Indian Ocean.]

1. Samoa; Museum Godeffroy; Cat. No. 1659.-One specimen with 26 arms about $100 \mathrm{~mm}$. long; three of the IIBr series are 2, and seven are $4(3+4)$.

2. No locality; Cat. No. 4134.-One specimen with 31 arms about $80 \mathrm{~mm}$. long.

\section{COMANTHUS TRICHOPTERA (J. Muller).}

[For the synonymy, see The Recent Crinoids of Australia.]

1. Southwestern Australia.-Two specimens. (See Die Fauna Südwest-Australiens, vol. 3, Lief. 13, p. 456.)

\section{COMANTHUS WAHLBERGII (J. Miiller).}

[For the synonymy, see Proc. U. S. Nat. Mus., vol. 40, p. 17.]

1. Port Natal; Herr Wahlberg; Cat. No. 1060.-Two specimens; one of these has 20 arms, all the IIBr series being present, and all $4(3+4)$; the arms are $45 \mathrm{~mm}$. long; the cirri are XIII, 15-16 (usually the latter), $10 \mathrm{~mm}$. long; in all cases the fifth is a transition segment; the first segment is very short, the following increasing in length so that the fifth is twice as long as its proximal diameter; the sixth is nearly as long; the eighth or ninth and following are slightly broader than long; the transition and following segments 
voL. 43 .

have slightly everted distal dorsal edges, which appear as minute sharp subterminal tubercles in lateral view, on the last few segments becoming a submedian transverse ridge, not resolving into a spine; the opposing spine is blunt, forked, or represented by a short transverse ridge. The dorsal pole of the centrodorsal is flat, rather large, $2.5 \mathrm{~mm}$. in diameter. The other specimen is similar.

These are part of Müller's type material; his other specimens are at Stockholm.

\section{COMANTHUS ANNULATA (Bell).}

[For the synonymy, see The Crinoids of the Indian Ocean.]

1. Friedrich-Wilhelms-Haven, New Guinea; Herr H. Schöde.-One large specimen with 40 arms.

2. St. Mathias Island; Herr H. Schöde.-Three specimens, each with about 40 arms; as in the preceding the centrodorsal is much reduced; all three have nearly all of the division series 2 instead of $4(3+4)$.

3. Batjan; Prof. E. von Martens; Cat. No. 1351.-One specimen with 41 arms about $100 \mathrm{~mm}$. long; three cirri remain.

4. Western Australia._Five specimens. (See Die Fauna SüdwestAustraliens, vol. 3, Lief. 13, p. 457.)

\section{COMANTHUS PARVICIRRA (J. Miller).}

[For the synonymy, see Proc. U. S. Nat. Mus., vol. 40, p. 18.]

1. Amoy, China; Cat. No. 5352.-Five specimens; one has $15 \mathrm{arms}$ about $80 \mathrm{~mm}$. long, three have 12 arms, $95 \mathrm{~mm}$., $90 \mathrm{~mm}$., and $45 \mathrm{~mm}$. long, respectively, and the fifth has 10 arms $35 \mathrm{~mm}$. long.

2. Ovalao, Fiji; Herr Arkona; Cat. No. 2405.-One specimen.

3. Amboina; Dr. J. Brock; Cat. No. 5248.-One specimen with 28 arms about $100 \mathrm{~mm}$. long; six of the $\mathrm{IIBr}$ series are 2, and four are $4(3+4)$; five of the IIIBr series are 2 , and three are $4(3+4)$; only small rudimentary cirri remain. This specimen has already been recorded by Hartlaub. (See Die Comatulidenfauna des Indischen Archipels, p. 97.)

4. Friedrich-Wilhelms-Haven, New Guinea; Herr H. Schöde.Three specimens; two are of medium size with about $20 \mathrm{arms}$, and one is rather larger with about 27 arms; all three have a few cirri remaining.

5. Atapupu, Timor; Prof. E. von Martens; Cat. No. 1647.-Two specimens, one with one, the other with no cirri; both have about 20 arms; one has four IIBr series in place, three 2, and one $4(3+4)$; the other has five in place, two 2 , and three $4(3+4)$.

6. Batjan; Prof. E. von Martens; Cat. No. 1351.-One specimen with 41 arms about $100 \mathrm{~mm}$. long; three cirri remain.

7. No locality.-Two specimens. 


\section{Family ZYGOMETRIDA.}

ZYGOMETRA MICRODISCUS (Bell).

[For the synonymy, see The Recent Crinoids of Australia.]

1. Western Australia.-Two specimens. (See Die Fauna SüdwestAustraliens, vol. 3, Lief. 13, p. 458.)

2. Mermaid, northwestern Australia.-One specimen. (See Zool. Anzeiger, vol. 34 , No. $11 / 12$, p. 367.)

\section{ZYGOMETRA ELEGANS (Bell).}

[For the synonymy, see The Recent Crinoids of Australia.]

1. Western Australia.-One specimen. (See Die Fauna SüdwestAustraliens, vol. 3, Lief. 13, p. 458.)

2. Mermaid, northwestern Australia.-Four specimens. (See Zool. Anzeiger, vol. 34 , No. 11/12, p. 367.)

\section{Family HIMEROMETRID王. \\ AMPHIMETRA AFRICANA A. H. Clark.}

Amphimetra africana A. H. Clark, Proc. U. S. Nat. Mus., vol. 40, 1911, p. 20.

1. Bagamoyo, German East Africa; Cat. No. 4616.-Five specimens; one of these served as the type of the species; ${ }^{1}$ the other four are very young with arms about $20 \mathrm{~mm}$. long and cirri about $6 \mathrm{~mm}$. long; two have 10 and two 11 arms.

This species appears to be nearest to A. philiberti of the East Indies, but it is a smaller, more slender and less rugged form with fewer arms and much longer cirrus spines.

AMPHIMETRA DISCOIDEA A. H. Clark.

[For the synonymy, see The Crinoids of the Indian Ocean.]

1. Western Australia.-One specimen. (See Die Fauna SüdwestAustraliens, vol. 3, Lief. 13, p. 459.)

\section{CRASPEDOMETRA ATER A. H. Clark.}

Alecto savignii (part) J. Müller, Monatsb. k. preuss. Akad. Wiss., 1841, p. 185; Archiv Naturg., 1841, vol. 1, p. 144.

Craspedometra ater A. H. Clark, Proc. U. S. Nat. Mus., vol. 40, 1911, p. 21.

1. Red Sea; Hempricht and Ehrenberg; Cat. No. 1055.-One specimen, the type of the species. (See Proc. U. S. Nat. Mus., vol. 40, p. 21.)

\section{CRASPEDOMETRA MADAGASCARENSIS A. H. Clark.}

Craspedometra madagascarensis A. H. Clark, Proc. U. S. Nat. Mus., vol. 40, 1911, p. 23.

1. Madagascar; Doctor Voeltzkow; Cat. No. 5348.--Three specimens; one of these, the type of the species, has already been described 
in detail $;^{1}$ one of the other specimens has 18 arms about $90 \mathrm{~mm}$. long; six IIBr series are present, five $4(3+4)$ and one 2 ; one of the IIBr $4(3+4)$ series bears internally a IIIBr series; the IIBr 2 series bears a IIIBr $4(3+4)$ series externally. The color of this specimen is purple. The third example has 13 arms $65 \mathrm{~mm}$. long, the three IIBr series being $4(3+4)$; the cirri are XVI, 32-33, $20 \mathrm{~mm}$. long; the color is brownish white, the cirri light purple.

This species is easily distinguished from Amphimetra africana by the tapering cirri which bear shorter dorsal spines, by the much more slender lower pinnules, and by the longer wedge-shaped brachials.

\section{HIMEROMETRA MAGNIPENNA A. H. Clark.}

Himerometra magnipinna A. H. Clark, Smiths. Misc. Coll. (Quarterly Issue), vol. 52, 1908, p. 214.

1. St. Mathias Island; Herr H. Schöde.-One fine specimen.

\section{HIMEROMETRA CRASSIPINNA (Hartlaub).}

[For the synonymy, see The Crinoids of the Indian Ocean.]

1. British North Borneo; Herr Pagel; Cat. No. 4744.-One specimen, resembling others at hand from Singapore, though the proximal cirrus segments are a trifle shorter.

2. Singapore; Prof. E. von Martens; Cat. No. 5373.-One specimen, which served Doctor Hartlaub as the type of his Antedon martensi. (See Die Comatulidenfauna des Indischen Archipels, p. 21, pl. 1, figs. 3 and 6 .)

This is a rather small and badly broken specimen, but it agrees in every particular with numerous specimens of $H$. crassipinna from Singapore at hand belonging to the Copenhagen Museum. (See Vidensk. Medd. fra den Naturhist. Forening i København, 1909, p. 155.)

\section{HETEROMETRA SAVIGNII (J. Müler).}

[For the synonymy, see Proc. U. S. Nat. Mus., vol. 40, p. 24.]

1. Red Sea; Hempricht and Ehrenberg; Cat. No. 1056.-One specimen, which was a part of Müller's type material. The centrodorsal is discoidal, moderately thick, with a flat dorsal pole $3 \mathrm{~mm}$. in diameter; the cirrus sockets are arranged in two and a partial third alternating marginal rows.

The cirri are about $20 \mathrm{~mm}$. long with from 23 to 25 segments, but the best developed cirri are all broken off; long and prominent dorsal spines are developed from the twelfth segment onward. 
No basal rays are visible; the radials are even with the edge of the centrodorsal in the median line, slightly visible as low triangles in the interradial angles; the $\left[\mathrm{Br}_{1}\right.$ are slightly over three times as broad as long, the lateral edges nearly straight, parallel, united in the proximal half but separated in the distal half by a moderately broad $U$-shaped gap; the $\mathrm{IBr}_{2}$ are broadly pentagonal, twice as broad as long; the division series are well rounded dorsally and well separated laterally, the sides being perfectly smooth, with no trace of lateral production.

There are 20 arms $125 \mathrm{~mm}$. long; all the IIBr series are present, and all are $4(3+4)$.

The lower pinnules are very long, but slender and perfectly smooth; the arms are perfectly smooth dorsally.

2. No locality; Cat. No. 5371.-One specimen. The cirri are XXXVI, 30, $24 \mathrm{~mm}$. long; long and prominent dorsal spines are developed from the eighteenth segment onward.

There are 20 arms, all the IIBr series being present, and all are $4(3+4)$.

$P_{1}$ is $9 \mathrm{~mm}$. long, tapering rather rapidly in the first 4 segments and becoming very slender and flagellate distally. $P_{2}$ is about $13 \mathrm{~mm}$. long and resembles $P_{3} ; P_{3}$ is $14 \mathrm{~mm}$. long with 21 segments of which the first is twice as broad as long, the following gradually increasing in length and becoming about as long as broad on the fourth and about twice as long as broad in the distal portion; the pinnule is slender, tapering evenly to a delicate tip, and is perfectly smooth with no trace of proximal carination or of a supplementary ridge such as is seen on the large proximal pinnules in the majority of the species of the genus; the segments fit closely end to end, without any cutting away of the corners; $\mathrm{P}_{4}$ is $6 \mathrm{~mm}$. long with 12 segments, a little less stout basally than $P_{3}$, but tapering more rapidly; the outer segments are twice as long as broad; $\mathrm{P}_{5}$ is $5 \mathrm{~mm}$. long, proportionately smaller than $\mathrm{P}_{4}$, with slightly shorter segments.

3. Red Sea; Hempricht and Ehrenberg; Cat. No. 1054.-Two specimens, similar to those described; both have 20 arms, all the $I I B r$ series being present, all $4(3+4)$.

4. Tor, Red Sea (Museum für Meereskunde).-One specimen.

The chief characteristics of this species are the strongly rounded and well-separated rays and division series, which do not have produced margins; the very long and slender, perfectly smooth and evenly tapering $\mathrm{P}_{2}$ and $\mathrm{P}_{3}$; and the long spines on the outer cirrus segments. The whole animal has a strikingly smooth appearance. All the specimens have exactly 20 arms, all the IIBr series being present, all $4(3+4)$. The color of all the specimens is dark brown. 


\section{Family STEPHANOMETRIDÆ.}

\section{STEPHANOMETRA TUBERCULATA (P. H. Carpenter).}

[For the synonymy, see The Crinoids of the Indian Ocean.]

1. New Guinea; Cat. No. 5347.-One specimen with 15 arms about $60 \mathrm{~mm}$. long; one $I I I B r$ series is developed (externally); $\mathrm{P}_{2}$ is $9 \mathrm{~mm}$. long with 10 greatly elongated segments; $P_{3}$ is similar to it, but smaller, $6 \mathrm{~mm}$. long, with 8 segments; $\mathrm{P}_{4}$ has 8 segments of which the outer resemble those of the preceding pinnules; it is $4 \mathrm{~mm}$. long and slightly stiffened; $\mathrm{P}_{2}$ and $\mathrm{P}_{3}$ are comparatively slender, possibly because of the small size of the animal.

2. No locality; Cat. No. 5287.-One large specimen with 33 arms $100 \mathrm{~mm}$. long.

The cirri are XXXV, 18-25 (usually the latter), 15 to $25 \mathrm{~mm}$. long (the latter the length of the peripheral cirri); the first two segments are very short, the following gradually increasing in length so that the fourth or fifth is about as long as broad; the following are about as long as broad or slightly longer than broad, after the middle of the cirrus gradually becoming shorter so that the segments in the outer third are slightly broader than long; the short distal segments are strongly compressed laterally and bear a faint median dorsal carination; there are no dorsal spines; the opposing spine is prominent, subterminal, directed obliquely forward; the terminal claw is slightly longer than the penultimate segment, stout, rather strongly curved.

The sides of the ossicles of the division series and of the first two brachials are produced into prominent flangelike borders which, however, are comparatively narrow.

$P_{1}$ is $10 \mathrm{~mm}$. long, slender and flagellate, with 20 segments of which the first is twice as broad as long, the third about as long as broad, and the following gradually increase in length so that the distal are three times as long as broad; $\mathrm{P}_{2}$ is stout and very stiff, $13.5 \mathrm{~mm}$. long with 14 segments of which the first is twice as broad as long, the third somewhat longer than broad, the fourth half again as long as broad, the fifth twice as long as broad, and the remainder nearly three times as long as broad; $\mathrm{P}_{3}$ is $9 \mathrm{~mm}$. long with 10 segments, similar to $\mathrm{P}_{2}$, but with the segments proportionately more elongated; $\mathrm{P}_{4}$ is small, slender and weak, $4.5 \mathrm{~mm}$. long with 11 segments.

3. No locality; Cat. No. 5288.-One specimen.

The centrodorsal is low hemispherical, about $5 \mathrm{~mm}$. in diameter at the base, the dorsal pole $1.5 \mathrm{~mm}$. in diameter, approximately flat, studded with small deep pits representing obsolete cirrus sockets.

The cirri are XXVII, 21-22, 20 to $25 \mathrm{~mm}$. long, arranged in two and a partial third closely crowded alternating marginal rows; the 
longer proximal segments are half again as long as their proximal diameter, and have a slightly concave ventral profile so that their ends are prominent; the 10 outer segments are about as long as broad, and the distal, especially the last three or four, are rather strongly carinate dorsally; the opposing spine is prominent, subterminal; the terminal claw is stout, rather short, and strongly curved.

The 28 arms are about $100 \mathrm{~mm}$. long; all but one of the rays bear external IIIBr series; the exception to this regular order has the $\mathrm{IIBr}$ and the IIIBr series missing on one side.

$P_{1}$ is slender and flagellate, $7 \mathrm{~mm}$. long with about 17 segments; $P_{2}$ is stiff and spine-like, $12 \mathrm{~mm}$. long with 11 segments; $P_{3}$ is 10.5 to $11 \mathrm{~mm}$. long with 10 segments, very slightly more slender than $\mathrm{P}_{2} ; \mathrm{P}_{4}$ is 7.5 to $8 \mathrm{~mm}$. long with 9 or 10 segments, much smaller than $\mathrm{P}_{3}$ though more or less like it distally; $\mathrm{P}_{5}$ is 4.5 to $5 \mathrm{~mm}$. long with 10 segments, slender and weak; the following pinnules are short and soft with short segments.

\section{STEPHANOMETRA TENUIPINNA (Hartlaub).}

Antedon tenuipinna Hartlaub, Nachr. Ges. Göttingen, Mai, 1890, p. 178.

1. New Britain; Dr. O. Finsch; Cat. No. 5374.--One specimen, the type of the species. (See Die Comatulidenfauna des Indischen Archipels, p. 54, pl. 3, figs. 28, 30, and 34.)

\section{Family PONTIOMETRIDÆ.}

\section{PONTIOMETRA ANDERSONI (P. H. Carpenter).}

[For the synonymy, see Vid. Medd. Naturh. For. Kфbenhavn, 1909, p. 165.]

1. Singapore; Prof. E. von Martens; Cat. Nos. 5351 and 5372.Two cirri and a detached visceral mass.

\section{Family MARIAMETRIDE.}

\section{SELENEMETRA FINSCHII (Hartlaub).}

Antedon finschii Hartuaub, Nachr. Ges. Göttingen, Mai, 1890, p. 176.

1. New Britain; Dr. O. Finsch; Cat. No. 2602.-Two specimens, the types of the species. (See Die Comatulidenfauna des Indischen Archipels, p. 47, pl. 3, fig. 32.)

\section{DICHROMETRA PROTECTUS (Lütken).}

[For the synonymy, see The Crinoids of the Indian Ocean.]

1. Tonga Islands; Museum Godeffroy; Cat. No. 3047.-Three 40armed specimens.

2. New Guinea; Cat. No. 2981.- Seventeen medium-sized and small specimens. The largest has 51 arms about $80 \mathrm{~mm}$. long; most of the specimens have about 40 arms.

3. Java; Herr Jagor; Cat. No. 1845.-One small specimen. 
4. Singapore; Herr Jagor; Cat. No. 2456.-One small specimen with 27 arms about $70 \mathrm{~mm}$. long. It is rather poorly preserved so that the large size of the outer pinnules is difficult to appreciate. The outer 10 or 11 cirrus segments have small sharp median tubercles. The very small size of $P_{1}$ and the great difference in size between $P_{2}$ and the two adjacent pinnules show that this individual belongs to $D$. protectus and not to D. palmata, under which name it was recorded by Hartlaub. (See Die Comatulidenfauna des Indischen Archipels, p. 51.)

5. Bougainville Island, Solomon Group; Gazelle.-Two specimens. (See Zool. Anzeiger, vol. 34, No. 11/12, p. 367.)

6. Salawatti; Gazelle.-Two specimens. (See Zool. Anzeiger, vol. 34 , No. $11 / 12$, p. 367 .)

7. No locality; Cat. No. 5334.--One specimen.

DICHROMETRA TENERA (Hartlaub).

[For the synonymy, see The Crinoids of the Indian Ocean.]

1. Western Australia.-Three specimens. (See Die Fauna Südwest-Australiens, vol. 3, Lief. 13, p. 460.)

DICHROMETRA FLAGELLATA (J. Müller).

[For the synonymy, see Notes from the Leyden Museum, vol. 33, p. 184.]

1. Singapore; Prof. J. Müller; Cat. No. 1282.-One specimen.

DICHROMETRA PALMATA (J. Müller).

[For the synonymy, see Proc. U. S. Nat. Mus., vol. 40, p. 27.]

1. Um-el-Terman, Gulf of Suez; Dr. R. Hartmeyer; Cat. No. 5604.-One specimen.

The centrodorsal is thick discoidal with a flat dorsal pole $2.5 \mathrm{~mm}$. in diameter; the cirrus sockets are arranged in two irregular closely crowded rows.

The cirri are XIV, 24-25 (usually the former), $20 \mathrm{~mm}$. long; the longer proximal segments are about one-third longer than broad; the outer 8 or 10 segments are slightly broader than long and bear a well-marked median dorsal keel which on the outermost shortens into a small tubercle.

There are 30 arms $115 \mathrm{~mm}$. long; the division series are well rounded dorsally and well separated laterally; the arms are perfectly smooth dorsally.

$P_{1}$ is $13 \mathrm{~mm}$. long with 28 segments; it tapers rather rapidly for the first four segments, then becoming more slender and tapering gradually to the tip; the first segment is about twice as broad as long, the following gradually increasing in length so that the fourth is about as long as broad, the segments beyond the seventh about one-third again as long as broad, and the terminal half again as long as broad; the first three segments have their distal angles slightly cut away, but 
this feature is absent from those following. $\mathrm{P}_{2}$ is $14 \mathrm{~mm}$. or $15 \mathrm{~mm}$. long with 30 segments, slightly stouter and stiffer than $P_{1}$ and tapering more evenly from the base, though otherwise exactly resembling it. $P_{3}$ is $11 \mathrm{~mm}$. long with 23 segments of which the distal, as in $P_{2}$, are about twice as long as broad; the pinnule is about as stont basally as $\mathrm{P}_{1}$, but tapers very evenly and gradually; it is considerably more slender than $\mathrm{P}_{2} . \quad \mathrm{P}_{4}$ is $6.5 \mathrm{~mm}$. long with 17 segments, and is essentially like $P_{3}$. $\quad P_{5}$ is $5.5 \mathrm{~mm}$. long with 16 segments, and resembles $\mathrm{P}_{4}$. The following pinnules resemble $\mathrm{P}_{5}$, later becoming longer and more slender. The distal pinnules are 8 to $9 \mathrm{~mm}$. long, very. slender, with from 19 to 21 segments.

This specimen is dull flesh color with broad bands of black on the arms; the dorsal half of the cirri is dull flesh color, the ventral half black.

2. Red Sea; Herr Umlauff; Cat. No. 2019.-One specimen with 30 arms $135 \mathrm{~mm}$. long.

The centrodorsal is thick discoidal with slightly sloping sides, the dorsal pole flat, $4 \mathrm{~mm}$. in diameter; the cirrus sockets are arranged in three closely crowded marginal rows.

The cirri are from 17 to $20 \mathrm{~mm}$. long and are composed of 24 or 25 segments, of which the outer are carinate; the longer proximal segments are slightly longer than broad, the short distal segments being slightly broader than long.

3. Red Sea; Hempricht and Ehrenberg; Cat. No. 2454.-One small badly broken specimen.

4. Ras-el-Millan, Red Sea; Dr. R. Hartmeyer; Cat. No. 5602.One specimen with 24 arms $90 \mathrm{~mm}$. long, resembling the one described in detail. As is always the case in this species, the IIIBr series are externally developed.

5. Red Sea; Hempricht and Ehrenberg; Cat. No. 1059.--One specimen with 30 arms $110 \mathrm{~mm}$. long.

6. Red Sea; Hempricht and Ehrenberg; Cat. No. 1057.-One specimen with 30 arms, similar to the preceding.

7. Dar-es-Salam, Red Sea; Cat. No. 4169.-Fragments.

8. No locality.-Two specimens.

Hartlaub's Antedon klunzingeri ${ }^{1}$ is identical with this species.

\section{Family COLOBOMETRID正.}

\section{CENOMETRA EMENDATRIX (Bell).}

[For the synonymy, see Proc. U. S. Nat. Mus., vol. 40, p. 28.]

1. Mauritius; Prof. K. Möbius; Cat. No. 5349.--One almost perfect specimen. (For a detailed description of this specimen, see Proc. U. S. Nat. Mus., vol. 40, p. 28.) 
CYLLOMETRA ALBOPURPUREA A. H. Clark.

[For the synonymy, see The Crinoids of the Indian Ocean.]

1. Japan; Dr. F. Hilgendorf; Cat. No. 2829.-Detached arms.

DECAMETRA INFORMIS (P. H. Carpenter).

[For the synonymy, see The Crinoids of the Indian Ocean.]

1. Singapore; Prof. E. von Martens; Cat. No. 5353.-One small specimen with arms about $20 \mathrm{~mm}$. long. In this small specimen $P_{2}$ is composed of longer segments than in the fully grown, and $P_{3}$ is proportionately shorter. The number of segments in $\mathrm{P}_{2}$, however, and their overlapping and spinous distal edges agree with $D$. informis, of which this appears to be the young.

DECAMETRA STUDERI (A. H. Clark).

[For the synonymy, see The Crinoids of the Indian Ocean.]

1. Dirk Hartog Island, Western Australia, 7 fathoms; Gazelle.One specimen. (See Zool. Anzeiger, vol. 34, No. 11/12, p. 368.)

DECAMETRA MODICA A. H. Clark.

Decametra modica A. H. Clark, Proc. U. S. Nat. Mus., vol. 40, 1911, p. 32.

1. Bagamoyo, German East Africa; Cat. No. 4616.--Three specimens. (See Proc. U. S. Nat. Mus., vol. 40, p. 32.)

DECAMETRA MÖBIUSI A. H. Clark.

Decametra möbiusi A. H. Clark, Proc. U. S. Nat. Mus., vol. 40, 1911, p. 31.

1. Mauritius; Prof. K. Möbius; Cat. No. 5349.-One specimen. (See Proc. U. S. Nat. Mus., vol. 40, p. 31.)

\section{OLIGOMETRA JAPONICA (Hartlaub).}

Antedon japonica Hartlaub, Nachr. Ges. Göttingen, Mai 1890, p. 172.

1. Japan; Dr. F. Hilgendorf; Cat. No. 5606.-One specimen.

The cirri are XXI, 21-23 (usually nearer the latter), $11 \mathrm{~mm}$. long; the cirrus segments are subequal, the outer slightly broader than long; on the sixth a subterminal transverse ridge appears which becomes median on the last one or two before the penultimate; this transverse ridge is very low and inconspicuous, most conspicuous on the last two or three segments, where it is very narrow and may become reduced to a small tubercle; the opposing spine is subterminal, and leans slightly anteriorly; it reaches in height about one-third of the distal diameter of the penultimate segment. (For a detailed description of this specimen, see Die Comatulidenfauna des Indischen Archipels, p. 84, pl. 5, fig. 49.) 
OLIGOMETRA SERRIPINNA OCCIDENTALIS A. H. Clark.

Oligometra serripinna var. occidentalis A. H. Clark, Proc. U. S. Nat. Mus., vol. 40,1911, p. 33.

1. Fouquet Island, near Mauritius; Prof. K. Möbius.-One small specimen. (See Proc. U. S. Nat. Mus., vol. 40, p. 33.)

2. Bagamoyo, German East Africa.-One specimen.

COLOBOMETRA VEPRETUM A. H. Clark.

Colobometra vepretum A. H. Clark, Vid. Medd. Naturh. For. København, 1909, p. 174.

1. Singapore; Prof. E. von Martens; Cat. No. 5351.-One arm fragment.

\section{Family TROPIOMETRIDÆ.}

TROPIOMETRA AUDOUINI, new species.

Tropiometra encrinus (part) A. H. Clark, Proc. U. S. Nat. Mus., vol. 40, 1911, p. 36 .

1. Eig Tor, Gulf of Suez; Dr. R. Hartmeyer; Cat. No. 5601.-One specimen.

Centrodorsal thick discoidal witn a single marginal row of cirrus sockets.

Cirri XVI, 18 (only one remaining), $13 \mathrm{~mm}$. long; the outer cirrus segments are about half again as broad as long.

The arms are about $80 \mathrm{~mm}$. long; the carination on the brachials is moderately developed.

The lower pinnules are very stiff, especially $\mathrm{P}_{2}, \mathrm{P}_{3}$ and $\mathrm{P}_{4} ; \mathrm{P}_{1}$ is 7 $\mathrm{mm}$. long with 16 segments; $P_{2}$ is $7 \mathrm{~mm}$. long with 14 segments, stouter basally than $\mathrm{P}_{1} ; \mathrm{P}_{3}$ is $6.5 \mathrm{~mm}$. long with 16 segments; $\mathrm{P}_{4}$ is 6 $\mathrm{mm}$. long with 16 segments; $\mathrm{P}_{2}, \mathrm{P}_{3}$ and $\mathrm{P}_{4}$ sometimes have spinelike tips resembling those of the proximal pinnules of the species of Stephanometra, and are very stiff; $\mathrm{P}_{1}$ is also more or less stiffened; $P_{5}$ is $6.5 \mathrm{~mm}$. long with 20 segments, slender, delicate, and distally flagellate, not stiffened like the preceding; $\mathrm{P}_{6}$ resembles $\mathrm{P}_{5}$; the distal pinnules are very slender.

2. Ras-el-Millan, Gulf of Suez; Dr. R. Hartmeyer; Cat. No. 5603.-One specimen, smaller than the preceding; the arms are about $50 \mathrm{~mm}$. long; the cirri are XXIII, 16-17, $13 \mathrm{~mm}$. long. Many of the cirri are small, from $9 \mathrm{~mm}$. long with 14 segments upward; these all appear to be juvenile cirri which will be lost before maturity is reached. The lower pinnules have the same sharp tips as those in the preceding example.

3. Aden; Prof. J. Müller; Cat. No. 1050.-One rather small specimen.

This new species is nearest to $T$. indica from Ceylon, from which it differs in having fewer cirri composed of fewer segments, and less $48702^{\circ}$-Proc.N.M.vol.43-12-26 
stiffened lower pinnules. In $T$. indica the cirri are XIX-XXIX (usually XXVI-XXIX), 20-26 (usually 23-26), 15 to $22 \mathrm{~mm}$. (usually 20 to $22 \mathrm{~mm}$.) long; the outer cirrus segments are half again as broad as long up to the fourth from the end of the cirrus; the antepenultimate segment is about as long as broad; the last four segments taper rather rapidly as usual. The cirri in T. indica are arranged in two or three (usually two and a partial third) marginal rows instead of in a single row, as in T. audouini.

The brachial carination in this species differs from that in $T$. indica in being broader, more rounded, and less sharp, and it is also fringed with coarser spines on its distal border.

Of $T$. indica 48 specimens have been examined, all from Ceylon or adjacent parts of India.

T. encrinus, with which I have previously confused both of these species, has much larger cirri, which resemble those of the American T. picta in having comparatively long instead of short segments in the distal portion.

TROPIOMETRA ENCRINUS A. H. Clark.

Tropiometra encrinus A. H. Clark, Proc. U. S. Nat. Mus., vol. 40, 1911, p. 36.

1. Eastern Asia; Cat. No. 5336.-One specimen, the type of the species.

The cirri are large and stout, XXIII, 20-23 (usually nearer the latter), 20 to $25 \mathrm{~mm}$. long; in the proportion of the component segments the cirri resembles those of T. picta. (See Proc. U. S. Nat. Mus., vol. 40, p. 36.)

2. Indian Ocean; Cat. No. 5335.-One specimen, much broken. The centrodorsal and calyx have been laid open, showing beautifully the relationships of the dorsal cavities of the calyx.

A specimen of this species in the collection of the Indian Museum labeled "?India" has the cirri XX, 23-25, 20 to $25 \mathrm{~mm}$. long, resembling those of the type.

TROPIOMETRA PICTA (Gay).

Tropiometra picta A. H. Clank, Proc. U. S. Nat. Mus., vol. 40, 1911, p. 35; Bull. mus. hist. nat. Paris, No. 4, 1911, p. 13 (255).

1. Santa Catarina Island, Brazil; Cat. No. 2875.-Two specimens.

The larger of these has the cirri XXV, 23-25, 20 to $25 \mathrm{~mm}$. long; the smaller has the cirri XIX, 20, $15 \mathrm{~mm}$. long.

2. Rio de Janeiro; Selenka; Cat. Nos. 1826 and 2690.--Thirty-nine specimens.

The details of the cirri of nine of these specimens are:

(1) XXII, 21-23 (usually 22 or 23 ), 24 to $28 \mathrm{~mm}$. long.

(2) XX, 20-21, $17 \mathrm{~mm}$. long. 
(3) XVII, 22-24, 23 to $25 \mathrm{~mm}$. long (a very large specimen.)

(4) XIX, 19-22, $20 \mathrm{~mm}$. long.

(5) XX, 20-23.

(6) XXIV, 21, 17 to $20 \mathrm{~mm}$. long.

(7) XIX, 21-25 (usually about 23), $20 \mathrm{~mm}$. long.

(8) XXII, 21-24, 20 to $22 \mathrm{~mm}$. long.

(9) XXII, 21-23, 20 to $23 \mathrm{~mm}$. long.

One of the specimens is interesting in possessing $11 \mathrm{arms}$, one IIBr 2 series being developed. This is the first time that the presence of $\mathrm{IIBr}$ series has been detected in this genus, though $T$. picta not infrequentiy has 12 arms through the presence of an additional ray. (See Bull. Mus. Comp. Zoöl., vol. 51, No. 8, p. 244, pl. 2.)

\section{TROPIOMETRA CARINATA (Lamarck).}

[For the synonymy, see Proc. U. S. Nat. Mus., vol. 40, p. 34.]

1. Madagascar; Doctor Hildebrandt; Cat. No. 2546.-One specimen, labeled "Actinometra solaris."

2. Mauritius; M. Guérin-Ménéville; Cat. No. 1038.-One specimen; the cirri are XIX, 21-23 (usually 22 or 23), $15 \mathrm{~mm}$. long; the carination on the arms is very greatly developed as in certain specimens of $T$. picta from Rio de Janeiro, each carinate process bearing a tuft of small spines. The color is purple.

3. Mauritius; Cat. No. 1037.--One specimen; the cirri are XXII, $23-26,20 \mathrm{~mm}$. long; the arms are about $80 \mathrm{~mm}$. long; the color is white, faintly blotched with light brown.

4. Fouquet Reef, Mauritius; Prof. K. Möbius; Cat. No. 5349.Twenty-six specimens. Details of six of the largest and most typical are:

(1) Cirri XV, 20-23 (usually the latter), $20 \mathrm{~mm}$. long; the dorsal pole of the centrodorsal is flat, $5 \mathrm{~mm}$. in diameter; the arms are very strongly carinate; the color is plain dark purple.

(2) Cirri XXIII, 21-24 (usually 22 or 23), $20 \mathrm{~mm}$. long; the dorsal pole of the centrodorsal is flat, $4 \mathrm{~mm}$. in diameter.

(3) Cirri XXVI, 21-25 (usually 23 or 24), $20 \mathrm{~mm}$. long; the arms are strongly carinate.

(4) Cirri XX, 22-24 (usually 23), 15 to $20 \mathrm{~mm}$. long; the arms are about $100 \mathrm{~mm}$. long.

(5) Cirri XX, 23-25 (usually 23), 15 to $20 \mathrm{~mm}$. long; the dorsal pole of the centrodorsal is flat, $7 \mathrm{~mm}$. in diameter.

(6) Cirri XIX, 22-23, 15 to $20 \mathrm{~mm}$. long.

In these specimens the carination of the brachials is usually prominent. The color is usually plain purple, but some specimens have narrow yellow bands in the distal part of the arms.

5. Zanzibar; Count von der Decken; Cat. No. 1636.--One specimen. 


\section{Family THALASSOMETRID虑.}

PTILOMETRA MACRONEMA (J. Müller).

[For the synonymy, see The Recent Crinoids of Australia.]

1. Southwestern Australia.-Nine specimens.

2. Dirk Hartog I., Western Australia; 7 fathoms.-One specimen. COSMIOMETRA CONIFERA (Hartlaub),

Antedon conifera Hartlaub, Nachr. Ges. Göttingen, Mai, 1890, p. 173.

1. Japan; Dr. F. Hilgendorf; Cat. No. 2830.-One badly broken specimen. (See Die Comatulidenfauna des Indischen Archipels, p. 76, pl. 4, fig. 46 ; pl. 5, figs. 51 and 56.)

\section{Family ANTEDONIDÆ. \\ Subfamily ANTHDONIN AE. \\ ANTEDON PETASUS (Diben and Koren).}

Alecto petasus DüBen and Koren, K. Vetensk. Akad. Handl., 1844 (1846), p. 229, pl. 6, fig. 1 .

1. Trondhjem; Larsen; Cat. No. 2887.-One specimen.

2. Florø; Prof. M. Sars; Cat. No. 1043.-One arm fragment.

3. Bodøfjord; Blochmann; Cat. No. 3618.-One specimen.

4. Bohuslän; Malm; Cat. No. 1308.-One specimen.

5. Norway; Cat. No. 1039.-Four specimens.

\section{ANTEDON MEDITERRANEA (Lamarck).}

[For the synonymy, see Notes from the Leyden Museum, vol. 33, p. 191.]

1. Naples; Zoölogical Station; Cat. Nos. 2351, 2352 and 2378.Two specimens, and larvæ.

2. Rovigno; Professor Möbius; Cat. No. 3547.-One specimen.

3. Sicily; Schultz; Cat. Nos. 3353 and 5339.-Twelve specimens; the cirri are from 18 to $21 \mathrm{~mm}$. long with from 19 to 25 segments.

4. Mediterranean; Peters; Cat. No. 5341.- Seven specimens; the arm length is from 50 to $60 \mathrm{~mm}$.; the cirri of the larger are $15 \mathrm{~mm}$. long with 21 or 22 segments.

5. Mediterranean; Cat. No. 1040.-One specimen with arms 85 $\mathrm{mm}$. long.

6. No locality; Cat. Nos. 1041, 1042, 5338, and 5340.-Eight specimens.

\section{ANTEDON ADRIATICA A. H. Clark.}

Antedon adriatica A. H. Clark, Proc. U. S. Nat. Mus., vol. 38, 1910, p. 329.

1. Trieste; Prof. J. Müller; Cat. No. 5342.-Seventy-one specimens; the larger have an arm length of about $100 \mathrm{~mm}$.; the cirri are XXIIXXVI, 24-29 (usually 26-28) $20 \mathrm{~mm}$. long; $\mathrm{P}_{1}$ is $12 \mathrm{~mm}$. long with 17 segments; $P_{2}$ is $7 \mathrm{~mm}$. long with 12 segments. 
2. Trieste; Dr. O. Hamann.--Seven specimens; the larger have an arm length of $110 \mathrm{~mm}$.; the cirri have from 21 to 27 segments (usually about 27) and are from 16 to $20 \mathrm{~mm}$. (usually from 18 to $20 \mathrm{~mm}$.) long.

(For the original description of this species, based in part upon these specimens, see Proc. U. S. Nat. Mus., vol. 38, pp. 329-333.)

\section{COMPSOMETRA INCOMMODA (Bell).}

[For the synonymy, see The Recent Crinoids of Australia.]

1. Southwestern Australia.-Two specimens. (See Die Fauna Südwest-Australiens, vol. 3, Lief 13, p. 464.)

\section{IRIDOMETRA MAURITIANA A. H. Clark.}

Iridometra mauritiana A. H. Clark, Proc. U. S. Nat. Mus., vol. 40, 1911, p. 40.

1. Fouquet, Mauritius; Prof. K. Möbius; Cat. No. 5349.-Thirtyfour specimens, including the type.

This species differs from $I$. nana, to which it appears to be mostt closely related, in having much stouter cirri, of which the component segments are much less constricted centrally; also $P_{1}$ is considerably larger than $\mathrm{P}_{2}$, and is stiffened.

\section{Subfamily ZFNOMHTRIN AE. \\ LEPTOMETRA PHALANGIUM (J. Mïller).}

[For the synonymy, see Proc. U. S. Nat. Mus., vol. 40, p. 44.]

1. Nice; Doctor Peters; Cat. No. 1044.-Four specimens.

2. Naples; Cat. No. 2377.-One specimen.

3. Sicily; Cat. No. 5343.- Seven specimens; these have their rays in close lateral contact.

4. No locality; Cat. No. 1045.-Three small broken specimens.

Subfamily HHLIOMF'NRIN $A$ A.

HELIOMETRA GLACIALIS (Leach).

[For the synonymy, see Vid. Medd. Naturh. For. København, 1909, p. 188.]

1. Kara Sea; Dijmphna; Cat. No. 3193.-One medium-sized specimen.

2. East Spitzbergen; Prof. W. Kükenthal; Cat. No. 3683.-One medium-sized specimen.

3. Belsund, west Spitzbergen; Leche; Cat. No. 3855.--One specimen.

4. Belsund, west Spitzbergen (Station No. 10); Römer and Schaudinn; Cat. No. 4413.-One specimen.

5. Spitzbergen (Stations Nos. 3, 6, 9, 10, 13, 24, 25, 32, 33, 34, 36, 37, 38, 49); Römer and Schaudinn.-Numerous specimens.

6. Greenland; Prof. J. Müller; Cat. No. 1046.-One specimen.

7. No locality; Cat. No. 5344.-Two medium-sized specimens. 
Carpenter's (Antedon) quadrata is a synonym of this species.

Very small specimens of this form have $\mathrm{P}_{3}$ more like $\mathrm{P}_{4}$ than like $\mathrm{P}_{2}$, and the borders, sometimes also the dorsal surface, of the ossicles of the $\mathrm{IBr}$ series and lower brachials are prominently spinous; with increasing size the spinosity gradually disappears, and $\mathrm{P}_{3}$ gradually comes to resemble $\mathrm{P}_{2}$ instead of $\mathrm{P}_{4}$.

HATHROMETRA PROLIXA (Sladen).

1. Spitzbergen; Römer and Schaudinn; Cat. No. 4391.-One specimen with arms $120 \mathrm{~mm}$. long; the longest cirri are $45 \mathrm{~mm}$. long with 38 segments; the apical cirri are $15 \mathrm{~mm}$. long with 22 segments which are proportionately shorter and more "dice-box shaped" than those of the peripheral cirri.

2. Spitzbergen; Römer and Schaudinn.-One specimen with an arm length of about $100 \mathrm{~mm}$.; $\mathrm{P}_{1}$ is $17 \mathrm{~mm}$. long with 31 segments, $\mathrm{P}_{2}$ is $7 \mathrm{~mm}$. long; the distal pinnules are $16 \mathrm{~mm}$. long. The cirrus segments appear to be a trifle shorter than usual.

3. Spitzbergen; Römer and Schaudinn; Cat. No. 4386.-One specimen.

4. Spitzbergen; Römer and Schaudinn; Cat. No. 4387.-Two specimens.

5. Spitzbergen; Römer and Schaudinn; Cat. Nos. 4389 and 4390.Two small specimens.

6. Spitzbergen (Stations Nos. 36, 37, 39); Römer and Scháudinn.Numerous specimens.

7. North Atlantic Ocean; Norwegian North Atlantic Expedition.Two specimens with an arm length of about $90 \mathrm{~mm}$.

The species of the genus Hathrometra are among the most difficult of the recent crinoids to determine on account of their excessive fragility. The chief differential characters are found in the cirri; but these are commonly, one might almost say usually, lost. Moreover the cirri of each individual are very variable in size, those about the periphery of the centrodorsal being twice as long as those about the dorsal pole, or even longer, and all possible gradations occurring. Only the peripheral cirri are of value in specific determination so that, unless these are preserved, identification becomes a matter of the very greatest difficulty. The number of these diagnostic cirri, as distinguished from the nondiagnostic subperipheral or polar cirri, is never very great; in large species like $H$. prolixa there are scarcely more than from half a dozen to a dozen, though in smaller species like $H$. sarsii the number of cirri available for systematic use is considerably greater.

Aside from the very great length and the large number of component ossicles in the diagnostic cirri of $H$. prolixa, these are somewhat abruptly larger than the other cirri and do not grade into them imper- 
ceptibly as is the case in the other species of the genus; this I find to be quite a characteristic feature.

In this species also the distal intersyzygial interval is usually four oblique muscular articulations instead of three as in the other forms. The greater size of the species accounts for this, however, as among the comatulids the distal intersyzygial interval is determined by the size of the animal and the number of arms, having only a remote and purely secondary relationship with generic or specific characters.

In fully grown specimens of this species the cirrus sockets near the periphery of the centrodorsal are arranged in four regular columns; of these the two outer consist of five or six sockets, but the two central have two (in smaller specimens one) sockets only, being distally replaced by a single column of three sockets, so that whereas in the proximal part of the centrodorsal there are four columns of cirrus sockets in each radial area in the distal there are but three. Young specimens of course have three columns of cirrus sockets in each radial area until the peripheral diameter of the centrodorsal is equal to the diameter through the lower sockets of the central columns in the centrodorsal of the adults.

Young specimens of this species, like young specimens of Heliometra glacialis, have the borders of the ossicles of the $\mathrm{IBr}$ series and lower brachials prominently spinous.

Carpenter and other authors have recorded Hathrometra tenella as occurring in the Arctic regions; but I have never been able to examine specimens of any species but prolixa from the Arctic, and I have a strong suspicion that the so-called tenella is merely the young of prolixa, or is based upon specimens which have lost their long and characteristic cirri. H. tenella is confined entirely to the western side of the Atlantic, and does not extend very far to the northward, not intruding at all upon the territory occupied by prolixa.

Though useless for ordinary systematic work the small subperipheral and polar cirri have a very great value in tracing out the line of descent of the species in which they occur; for each of these small cirri represents a fully grown cirrus at the stage in which the border of the centrodorsal was just beyond the proximal edge of its socket. The centrodorsal increases by addition to its proximal edge; when enough material has been added cirri are protruded between the proximal row of cirri and the border of the centrodorsal. These cirri grow to a certain length and attain certain definite characters. The cirri of the next row above grow to a greater length and possess a greater number of segments. This process keeps on until maturity is reached, after which the cirri of subsequent rows show no progressive change. The small polar and subperipheral cirri, the "small mature" cirri of Carpenter, are really persistent relics of successive young stages, and have no connection with the adult stage at all. 
HATHROMETRA DENTATA (Say).

1. East of New York; Albatross; Cat. No. 3244.-Five specimens. HATHROMETRA SARSII (Düben and Koren).

1. Bodøfjord; Cat. No. 3618.-One small specimen.

2. No locality; Prof. J. Müller; Cat. Nos. 5337, 1052, and 1053.-Six specimens.

\section{Family PENTAMETROCRINIDA.} PENTAMETROCRINUS TUBERCULATUS (A. H. Clark).

1. Japan; Dr. F. Hilgendorf; Cat. No. 2831.-Two specimens, badly broken.

One of these resembles the type of the species; the other is smaller and less tubercular. The cirri are all detached; the longest, which presumably came from the larger specimen, are from 18 to $22 \mathrm{~mm}$. in length and are composed of from 16-17 segments.

This species is easily recognized by its short cirri which have comparatively few segments, and by the strongly curved terminal claw.

Carpenter, in the Challenger report, tentatively referred these specimens to $P$. japonicus, evidently overlooking the very characteristic detached cirri.

\section{Family PENTACRINITIDÆ.}

ENDOXOCRINUS WYVILLETHOMSONI (Wyville Thomson).

1. Off Portugal, 2133 meters; Porcupine; Cat. No. 1932.-One specimen.

ISOCRINUS ASTERIA (Linnæus).

1. St. Thomas, 250-600 meters; Cat. No. 3028.-One specimen.

2. No locality; Cat. Nos. 5346 and 5345.-Fragments.

ISOCRINUS DECORUS (Wyville Thomson).

1. Barbados; 234 meters; Wyville Thomson; Cat. No. 2024.-One specimen.

METACRINUS MOSELEYI P. H. Carpenter.

1. Mindanao, Philippine Islands; Challenger; Cat No. 2271.-A stem fragment of five internodes.

METACRINUS ROTUNDUS P. H. Carpenter.

1. Sagami Bay, Japan.-One specimen.

Family BOURGUETICRINIDE.

RHIZOCRINUS ROBUSTUS A. H. Clark.

1. Gulf of Mexico; Albatross; Cat. No. 3246.-One specimen. 


\section{NOT IDENTIFIABLE.}

1. Mauritius; Professor Möbius; Cat. No. 5349.-One specimen.

2. Southern Indian Ocean; Gazelle.-One specimen of some species of Cyllometra. (See Zool. Anzeiger, vol. 34, p. 368.)

3. Northwestern Australia; Gazelle.-One specimen, possibly of Oligometra adeonæ. (See Zool. Anzeiger, vol. 34, p. 368.)

NOTE,

In the course of my studies on the recent crinoids I have examined the material contained in all of the chief museums of the world, and have published separate accounts of several of these collections in order that their study by subsequent investigators may be facilitated and my work the more readily reviewed.

This is the sixth paper to be published of the series dealing primarily with the collection of a single museum, the preceding five being:

(1) On a Collection of Crinoids from the Zoological Museum of Copenhagen. Vidensk. Medd. fra den Naturhist. Forening i København, 1909, pp. 115-194.

(2) The Recent Crinoids of the Leyden Museum. Notes from the Leyden Museum, vol. 33, pp. 175-192 (1911).

(3) Notes sur les crinoïdes actuels du muséum d'histoire naturelle de Paris. Bulletin du muséum d'histoire naturelle, 1911, No. 4, pp. 243-260.

(4) The Recent Crinoids of Australia. Australian Museum Memoirs, No. 4, 1911.

(5) The Crinoids of the Irdian Ocean. Investigator Monographs, 1912.

I hope soon to publish an account of the crinoids of the Hamburg Museum, and my notes upon the crinoids of the British Museum.

\section{LIST OF THE PAPERS CONTAINING REFERENCES TO THE CRINOIDS}

IN THE COLLECTION OF THE MUSEUM FUER NATURKUNDE.

1840. Müller, Johannes. Monatsb. k. preuss. Akad. Wiss. Berlin, 1840, p. 6; also in Wiegmann's Archiv für Naturgeschicte, 1840, vol. 1, p. 311; also in l'Institut, 17 sept., 1840, p. 394.

1841. — Ueber die Gattungen und Arten der Comatulen. Monatsb. k. preuss. Akad. Wiss., Berlin, 1841, pp. 179-189; also in Wiegmann's Archiv für Naturgeschicte, 1841, vol. 1, pp. 139-148.

1843. — Neue Beiträge zur Kenntniss der Arten der Comatulen. Wiegmann's Archiv für Naturgeschicte, 1843, vol. 1, pp. 131-136.

1843. - Ueber den Bau des Pentacrinus caput-Medusae. Abh.k. preuss. Akad. Wiss., Berlin, 1840 (1843), pp. 177-248; abstract in Monatsb. k. preuss. Akad. Wiss., Berlin, 1840, pp. 88-106.

1849. — Ueber die Gattung Comatula, Lam., und ihre Arten. Abh. k. preuss. Akad. Wiss., Berlin, 1847, pp. 237-265.

1862. Dujardin, F., and H. Hupé. Histoire naturelle des Zoophytes. Echinodermes. Paris. (Crinoids, pp. 35-218; the information regarding the specimens in the Berlin Museum is taken from Müller, 1849.) 
1869. Martens, E. von. In von der Decken, Reise in Ost-Africa in den Jahren 18591865. (Crinoids, vol. 3, p. 129.)

1877. Graff, L. von. Das Genus Myzostoma.

1879. Carpenter, Philip Herbert. On the Genus Actinometra, Müll., with a Morphological Account of a new Species from the Philippine Islands. Trans. Linn. Soc. London (Zool.), ser. 2, vol. 2, pt. 1, pp. 1-122. (Preliminary abstract in Journ. Linn. Soc. London (Zool.), vol. 13, pp. 439-456 (1877).)

1887. Graff, L. von. The Myzostoma. Challenger Reports, vol. 20, Zoology.

1888. Carpenter, Philip Herbert. Report on the Crinoidea collected during the voyage of H. M. S. Challenger. Part 2.-The Comatulæ. Challenger Reports, vol. 26, Zoology.

1889. Studer, Th. Die Forschungsreise S. M. S. Gazelle in den Jahren 1874 bis 1876. Theil 3. Zoologie und Geologie.

1890. Hartlaub, Clemens. Beitrag zur Kenntniss der Comatuliden-fauna des indischen Archipels. Nachr. Ges. Göttingen, Mai 1890, pp. 168-187.

1891. Beitrag zur Kenntniss der Comatuliden-fauna des indischen Archipels. Nova Acta Leop.-Carol. deut. Akad. Naturf., vol. 58, No. 1, pp. 1-120.

1905. Döderlein, Ludwig. Arktische Crinoiden. Fauna Arctica, vol. 4, pp. 395406.

1909. Clark, Austin Hobart. Two New Australian Crinoids. Proc. Biol. Soc. Washington, vol. 22 , pp. 39-42.

1909. — Systematic position of Oligometra studeri. Proc. Biol. Soc. Washington, vol. 22 , p. 88 .

1909. — The Crinoids of the Gazelle Expedition. Zoologischer Anzeiger, vol. 34, No. 11/12, pp. 363-370.

1910. — On the Type Specimen of the Crinoid described by Müller as Alecto purpurea. Proc. Biol. Soc. Washington, vol. 23, pp. 95-98, fig. p. 97.

1911. - The recent Crinoids of the Coasts of Africa. Proc. U. S. Nat. Mus., vol. 40 , pp. 1-51.

1911. C Crinoidea (of southwestern Australia). Die Fauna Südwest-Australiens; Ergebnisse der Hamburger südwest-Australischen Forschungsreise 1905, vol. 3, Lief. 13, pp. 435-467.

1911. — The Recent Crinoids of Australia. Memoir IV, Australian Museum, Sydney, N. S. W. Scientific Results of the Trawling Expedition of H. M. C. S. Thetis off the Coast of New South Wales, in February and March, 1898 Part 15, pp. 705-804.

1912. - The Crinoids of the Indian Ocean. Echinoderma of the Indian Museum, Part VII, Crinoidea. Calcutta. 


\section{$2 \mathrm{BHL}$ Biodiversity Heritage Library}

Clark, Austin Hobart. 1912. "The crinoids of the Museum fuer Naturkinde, Berlin." Proceedings of the United States National Museum 43, 381-410. https://doi.org/10.5479/si.00963801.43-1937.381.

View This Item Online: https://www.biodiversitylibrary.org/item/32782

DOI: https://doi.org/10.5479/si.00963801.43-1937.381

Permalink: https://www.biodiversitylibrary.org/partpdf/12261

\section{Holding Institution}

Smithsonian Libraries

\section{Sponsored by}

Smithsonian

\section{Copyright \& Reuse}

Copyright Status: NOT_IN_COPYRIGHT

This document was created from content at the Biodiversity Heritage Library, the world's largest open access digital library for biodiversity literature and archives. Visit BHL at https://www.biodiversitylibrary.org. 